\title{
Malignant Neoplasm Prevalence in the Aktobe Region of Kazakhstan
}

\author{
Yerbol Bekmukhambetov ${ }^{1}$, Arstan Mamyrbayev ${ }^{2}$, Timur Jarkenov ${ }^{3}$, Aliya \\ Makenova $^{4}$, Zina Imangazina ${ }^{5 *}$
}

\begin{abstract}
An oncopathological state assessment was conducted among adults, children and teenagers in Aktobe region for 2004-2013. Overall the burden of mortality was in the range of 94.8-100.2 per 100,000 population, without any obvious trend over time. Ranking by pathology, the highest incidences among women were registered for breast cancer (5.8-8.4), cervix uteri (2.9-4.6), ovary (2.4-3.6) and corpus uteri, stomach, esophagus, without any marked change over time except for a slight rise in cervical cancer rates. In males, the first place in rank was trachea, bronchus and lung, followed by stomach and esophagus, which are followed by bladder, lymphoid and hematopoietic tissues pathology. Agian no clear trends were apparent over time. In children, main localizations in cancer incidence blood (acute lymphocytic leukemia, lymphosarcoma, acute myeloid leukemia, Hodgkin's disease), brain and central nervous system, bones and articular cartilages, kidneys, and eye and it's appendages, in both sexes. Similarly, in young adults, the major percentage was in blood and lymphatic tissues (acute myeloid leukemia, acute lymphocytic leukemia, Hodgkin's disease) a significant percentage accruing to lymphosarcoma, lymphoma, other myeloid leukemia and hematological malignancies as well as tumors of brain and central nervous system, bones and articular cartilages. This initial survey provides the basis for more detailed investigation of cancer epidemiology in Aktobe, Kazakhstan.
\end{abstract}

Keywords: Malignant neoplasms - mortality - oncopathology - adults - children - teenagers - Aktobe, Kazakhstan

Asian Pac J Cancer Prev, 16 (18), 8149-8153

\section{Introduction}

The monitoring of prevalence peculiarities, cancer morbidity patterns and mortality among rural and urban residents is an overriding issue, giving the necessary information about the health of adults and children. Epidemiological research pursued in Kazakhstan has shown that the pattern of laryngeal cancer, leukemia and breast cancer prevalence depends on ethnic and gender differences, unfavorable environmental conditions (Bilyalova et al., 2012; Igissinov et al., 2012; Igissinov et al., 2013) . Previous research has shown that technogenic chrome biogeochemical province has a direct impact on the prevalence of malignant tumors among the urban residents and cancer pathologymortality rate (Bekmukhambetov et al., 2015). In such case the health status of rural residents inhabiting Aktobe region, physical and sexual development indicators depend not only on the nature of food, but also on environmentally neglected territory of inhabitation (Mamyrbayev et al., 2013; Battakova et al., 2014; Bermagambetova et al., 2015) it cannot be ruled out that the consequences of nuclear explosions conducted in West Kazakhstan have an impact on development of malignancies among rural residents (Mamyrbayev et al., 2014; Urgushbaeva et al., 2015).

\section{Materials and Methods}

All epidemiological surveys are carried out on the territory of Aktobe region, which includes 12 districts. In the present paper the official oncological statistics of new cancer cases is used. The "crude" one and standardized by age and sex markers of malignant tumors incidence are calculated. Epidemiological analysis of cancer incidence and mortality, built upon 100 thousand people, is conducted since 2004 till 2013 by extracting of statistical material from registration forms f №7, f 030- y, f025-y, f 090-y, f № 35, as well as from Department of statistics. Standardization is conducted by direct method. The average annual rates of growth (loss) are calculated by method of regression analysis. The list of diseases was based on the 'International Classification of Diseases, Injuries and Causes of Death Manual, $10^{\text {th }}$ Edition'

\section{Results}

The total prevalence of cancer pathology (per 100,000

${ }^{1}$ Rector, ${ }^{2}$ Professor, ${ }^{3}$ Vice-Rector, West Kazakhstan Marat Ospanov State Medical University, ${ }^{4}$ West-Kazakhstan Branch of "National Center of Industrial Hygiene and Occupational Diseases", ${ }^{5}$ Doctoral candidate at West Kazakhstan Marat Ospanov State Medical University Kazakhstan Aktobe, Kazakhstan*For correspondence: zimangazina@gmail.com 
people) was as follows: in 2004 - 24.6; 2005 - 241.0; 2006 - 246.6; 2007 - 229.4; 2008 - 224.5; 2009 - 214.2; 2010 - 235.9; 2011 - 240.0; 2012 - 245.9; 2013 - 254.3. Analysis of malignant neoplasms prevalence among adults in Aktobe region for 2004-2013 is represented in Figures 1 and 2. Ranking pathology on-studies, the highest incidence among women is registered from breast cancer, cervix uteri, ovary and corpus uteri, stomach, esophagus; they are following by trachea, bronchus, lungs and bladder. Some what different situation of the malignant tumors incidence is diagnosed among men. The first place in rank takes trachea, bronchus, lung, stomach and esophagus oncopathology, which are followed by bladder, lymphoid and hematopoietic tissues pathology. At the same time the spectrum of malignant tumors prevalence is quite wide, it includes the localization of malignant tumors in other organs and tissues, what is quite rare.

Main localizations in the structure of cancer incidence among girls are blood (acute lymphocytic leukemia, lymphosarcoma, acute myeloid leukemia, Hodgkin's disease), brain and central nervous system, bones and articular cartilages, kidneys, eye and it's appendages, pancreas and ovary (Figure 3).

A substantial proportion of malignant neoplasms prevalence among boys also is detected in hematopoietic system (acute lymphocytic leukemia, lymphosarcoma, Hodgkin's disease, acute myeloid leukemia); followed by brain and central nervous system, bones and articular cartilages, kidneys, eye and it's appendages, bladder, pancreas and testicular (Figure 4).

The malignancies incidence among young women and men is represented on Figures 5 and 6. The major percentage in the structure of cancer incidence among

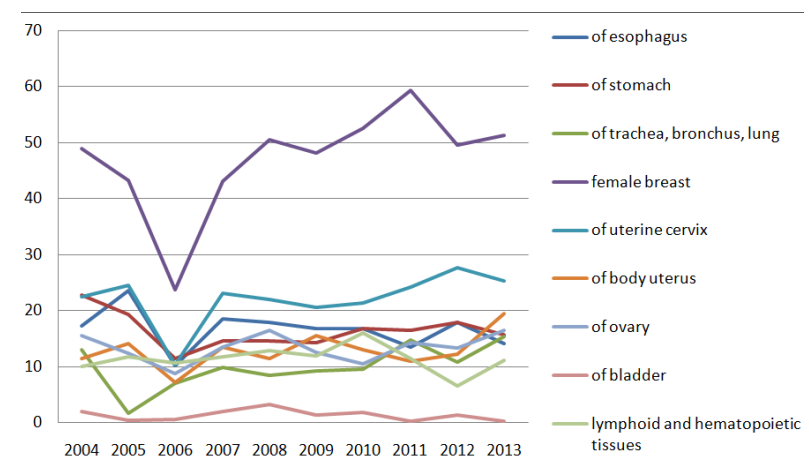

Figure 1. Oncopathology Prevalence among Women in Aktobe Region

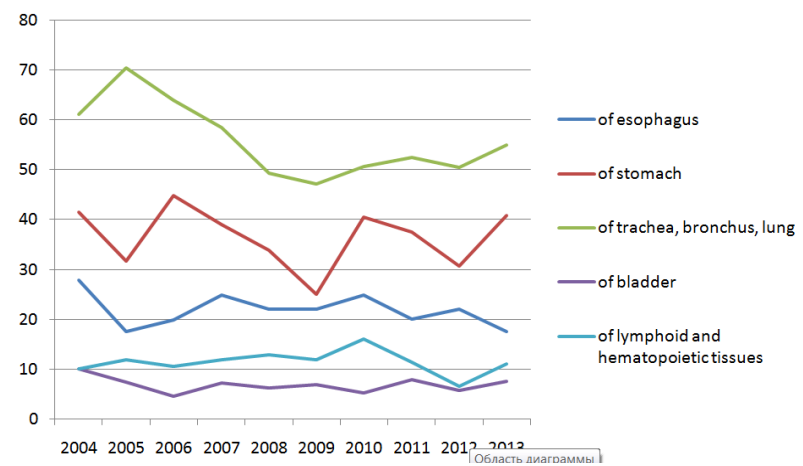

Figure 2. Oncopathology Prevalence among Men in Aktobe region women is detected in blood and lymphatic tissues (acute myeloid leukemia, acute lymphocytic leukemia, Hodgkin's disease). A significant percentage accrues to lymphosarcoma, lymphoma, other myeloid leukemia and hematological malignancies as well as tumors of brain and central nervous system, bones and articular cartilages. The similar trend is found during research of malignant neoplasms prevalence among young men: the

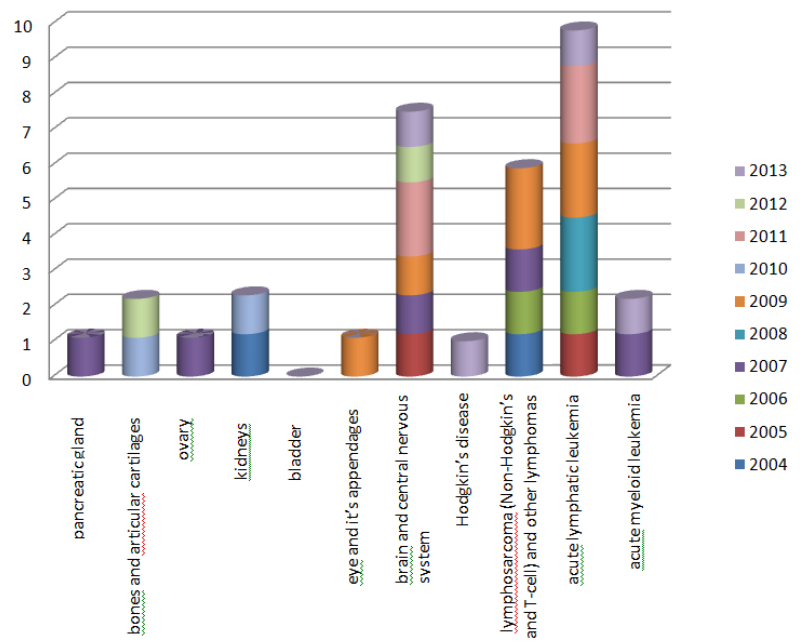

Figure 3. Oncopathology Prevalence among Juvenile Girls in Aktobe Region

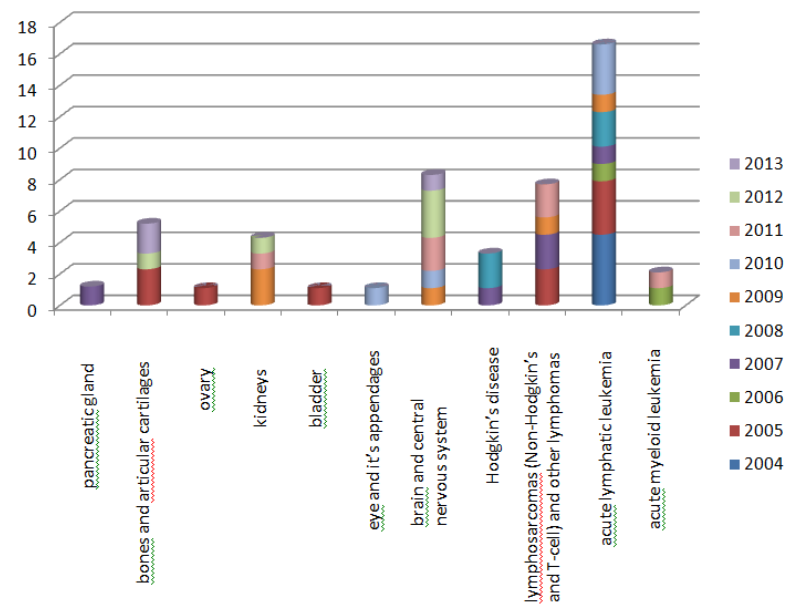

Figure 4. Oncopathology Prevalence among Juvenile Boys in Aktobe region

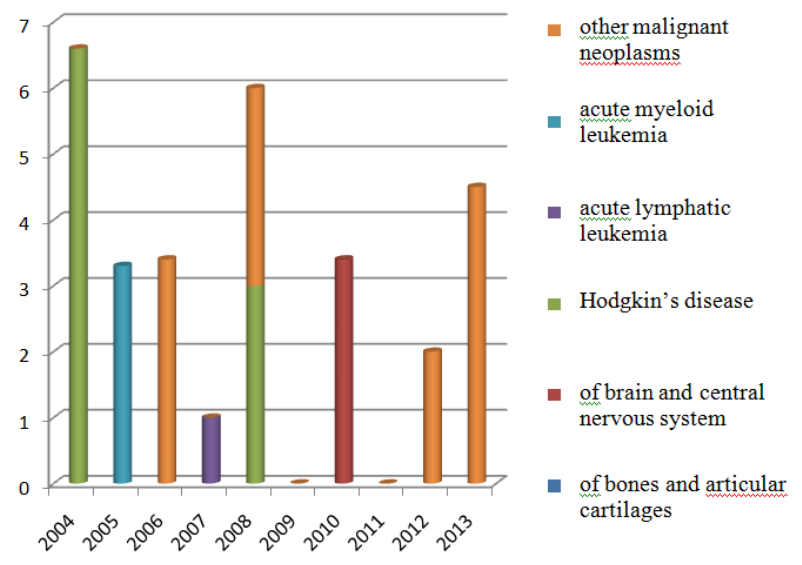

Figure 5. Prevalence of Oncopathology among Young Women of Aktobe Region

8150 Asian Pacific Journal of Cancer Prevention, Vol 16, 2015 
DOI:http://dx.doi.org/10.7314/APJCP.2015.16.18.8149 Peculiarities of Malignant Neoplasms Prevalence in Aktobe Region of Kazakhstan

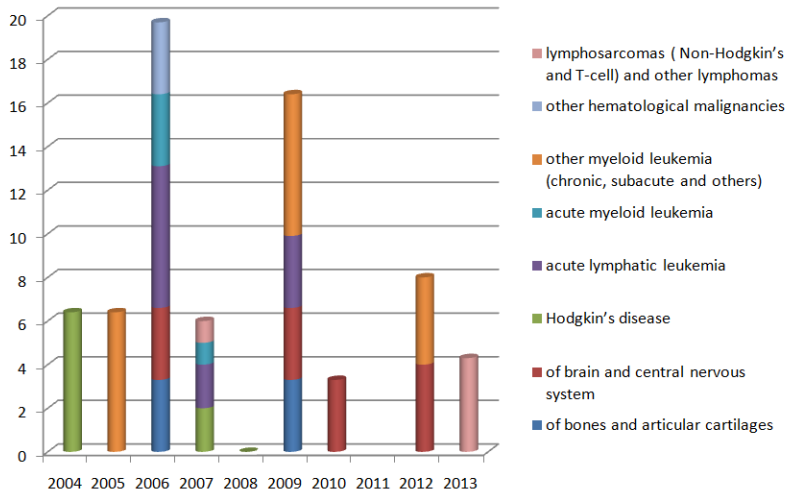

Figure 6. Oncopathology Prevalence among Young Men in Aktobe Region major proportion in the structure of cancer morbidity takes oncopathology of blood and lymphatic tissue; the proportion of brain and central nervous system, bones and articular cartilages, and skin tumors is quite significant.

The population mortality rate in Aktobe region caused by malignant neoplasms (per 100 thousand people) is presented in Table 1 . The cumulated measure of mortality rate both in absolute terms and per 100 thousand people during the study period (2004-2013) has a tendency to increase.

Top ten positions in the structure of both male and female population mortality (in absolute terms and per 100 thousand people) are ordered in the following way: first place - neoplasms of the trachea, bronchus, lung; the second - malignant tumors of the stomach; third

Table 1.1. Mortality Rate of Aktobe Region Caused by Oncopathology(per 100,000), 2004-2008

\begin{tabular}{|c|c|c|c|c|c|c|c|c|c|c|c|}
\hline \multirow[b]{2}{*}{ Tumor localization } & \multirow[b]{2}{*}{ ICD code $X$} & \multicolumn{2}{|c|}{2004} & \multicolumn{2}{|c|}{2005} & \multicolumn{2}{|c|}{2006} & \multicolumn{2}{|c|}{2007} & \multicolumn{2}{|c|}{2008} \\
\hline & & abs. & $\begin{array}{c}\text { per } \\
100000\end{array}$ & abs. & $\begin{array}{c}\text { per } \\
100000\end{array}$ & abs. & $\begin{array}{c}\text { per } \\
100000\end{array}$ & abs. & $\begin{array}{c}\text { per } \\
100000\end{array}$ & abs. & $\begin{array}{c}\text { per } \\
100000\end{array}$ \\
\hline Malignant neoplasms & $\mathrm{C} 00-\mathrm{C} 97$ & 666 & 98.1 & 714 & 104 & 732 & 105.3 & 653 & 92.8 & 736 & 97.3 \\
\hline Lips & $\mathrm{CO0}$ & 3 & 0.4 & 0 & 0 & 3 & 0.4 & 4 & 0.6 & 1 & 0.1 \\
\hline $\begin{array}{l}\text { Tongue, oral cavity and } \\
\text { pharynx }\end{array}$ & $\mathrm{C} 01-\mathrm{C} 14, \mathrm{C} 46.2$ & 26 & 3.8 & 20 & 2.9 & 13 & 1.9 & 12 & 1.7 & 25 & 3.3 \\
\hline Esophagus & $\mathrm{C} 15$ & 78 & 11.5 & 89 & 13 & 71 & 10.2 & 63 & 9 & 99 & 13.1 \\
\hline Stomach & $\mathrm{C} 16$ & 90 & 13.3 & 104 & 15.1 & 114 & 16.4 & 94 & 13.4 & 85 & 11.2 \\
\hline Segmented intestine & $\mathrm{C} 18$ & 29 & 4.3 & 24 & 3.5 & 24 & 3.5 & 23 & 3.3 & 29 & 3.8 \\
\hline $\begin{array}{l}\text { Rectum, rectosigmoid } \\
\text { junction, anus }\end{array}$ & C19-C21 & 16 & 2.4 & 18 & 2.6 & 22 & 3.2 & 26 & 3.7 & 30 & 4 \\
\hline Liver & $\mathrm{C} 22$ & 42 & 6.2 & 42 & 6.1 & 33 & 4.7 & 24 & 3.4 & 43 & 5.7 \\
\hline Pancreas & $\mathrm{C} 25$ & 17 & 2.5 & & 0 & 26 & 3.7 & 23 & 3.3 & 21 & 2.8 \\
\hline Larynx & $\mathrm{C} 32$ & 10 & 1.5 & 13 & 1.9 & 14 & 2 & 10 & 1.4 & 11 & 1.5 \\
\hline Trachea, bronchus, lung & C33 - C34 & 128 & 18.9 & 110 & 16 & 149 & 21.4 & 136 & 19.3 & 138 & 18.2 \\
\hline $\begin{array}{l}\text { Bones and articular } \\
\text { cartilages }\end{array}$ & $\mathrm{C} 40-\mathrm{C} 41$ & 8 & 1.2 & 14 & 2 & 8 & 1.2 & 6 & 0.9 & 4 & 0.5 \\
\hline $\begin{array}{l}\text { Connective and other } \\
\text { soft tissues }\end{array}$ & $\begin{array}{l}\text { C45,C46.1, C47, } \\
\text { C49 }\end{array}$ & 1 & 0.1 & 0 & 0 & 10 & 1.4 & 4 & 0.6 & 10 & 1.3 \\
\hline Skin melanoma & $\mathrm{C} 43$ & 2 & 0.3 & 6 & 0.9 & 2 & 0.3 & 3 & 0.4 & 4 & 0.5 \\
\hline Other skin cancers & $\mathrm{C} 44, \mathrm{C} 46.0$ & 21 & 3.1 & 1 & 0.1 & 4 & 0.6 & 1 & 0.1 & 0 & 0 \\
\hline Breast & $\mathrm{C} 50$ & 57 & 8.4 & 41 & 6 & 70 & 10.1 & 55 & 7.8 & 59 & 7.8 \\
\hline Uterine cervix & C53 & 20 & 2.9 & 23 & 3.3 & 17 & 2.4 & 25 & 3.6 & 29 & 3.8 \\
\hline Uterine body & C54 & 5 & 0.7 & 27 & 3.9 & 13 & 1.9 & 6 & 0.9 & 13 & 1.7 \\
\hline Ovary & $\mathrm{C} 56$ & 16 & 2.4 & 29 & 4.2 & 20 & 2.9 & 25 & 3.6 & 21 & 2.8 \\
\hline Prostate gland & C61 & 4 & 0.6 & 5 & 0.7 & 9 & 1.3 & 4 & 0.6 & 8 & 1.1 \\
\hline Testis & C62 & 1 & 0.1 & 1 & 0.1 & 2 & 0.3 & 4 & 0.6 & 1 & 0.1 \\
\hline Kidney & C64 & 18 & 2.7 & 17 & 2.5 & 12 & 1.7 & 13 & 1.8 & 8 & 1.1 \\
\hline Bladder & C67 & 4 & 0.6 & 21 & 3.1 & 8 & 1.2 & 4 & 0.6 & 12 & 1.6 \\
\hline $\begin{array}{l}\text { Eye and appendages of } \\
\text { the eye }\end{array}$ & C69 & 0 & 0 & 1 & 0.1 & 0 & 0 & 3 & 0.4 & 1 & 0.1 \\
\hline Brain and CNS & C70-C72 & 4 & 0.6 & 8 & 1.2 & 6 & 0.9 & 7 & 1 & 5 & 0.7 \\
\hline Thyroid body & $\mathrm{C} 73$ & 3 & 0.4 & 6 & 0.9 & 9 & 1.3 & 3 & 0.4 & 3 & 0.4 \\
\hline Malignant lymphomas & C81-C90 & 15 & 2.2 & 21 & 3.1 & 16 & 2.3 & 22 & 3.1 & 22 & 2.9 \\
\hline Leukemia & C91C95,C96 & 20 & 2.9 & 25 & 3.6 & 19 & 2.7 & 17 & 2.4 & 19 & 2.5 \\
\hline Others & & 28 & 4.1 & 48 & 7 & 38 & 5.5 & 36 & 5.1 & 35 & 4.6 \\
\hline
\end{tabular}


Table 1.2. Mortality Rate of Aktobe Region Caused by Oncopathology (per 100,000), 2009-2013

\begin{tabular}{|c|c|c|c|c|c|c|c|c|c|c|c|}
\hline \multirow[b]{2}{*}{ Tumor localization } & \multirow[b]{2}{*}{ ICD code $X$} & \multicolumn{2}{|c|}{2009} & \multicolumn{2}{|c|}{2010} & \multicolumn{2}{|c|}{2011} & \multicolumn{2}{|c|}{2012} & \multicolumn{2}{|c|}{2013} \\
\hline & & abs. & $\begin{array}{c}\text { per } \\
100000\end{array}$ & abs. & $\begin{array}{c}\text { per } \\
100000\end{array}$ & abs. & $\begin{array}{c}\text { per } \\
100000\end{array}$ & abs. & $\begin{array}{c}\text { per } \\
100000\end{array}$ & abs. & $\begin{array}{c}\text { per } \\
100000\end{array}$ \\
\hline Malignant neoplasms & C00-C97 & 724 & 94.8 & 746 & 96 & 727 & 92.5 & 765 & 96.1 & 811 & 100.3 \\
\hline Lips & $\mathrm{C} 00$ & 4 & 0.5 & 2 & 0.3 & 1 & 0.1 & 2 & 0.3 & 3 & 0.4 \\
\hline $\begin{array}{l}\text { Tongue, oral cavity and } \\
\text { pharynx }\end{array}$ & $\mathrm{C} 01-\mathrm{C} 14, \mathrm{C} 46.2$ & 21 & 2.8 & 24 & 3.1 & 30 & 3.8 & 24 & 3 & 24 & 3 \\
\hline Esophagus & $\mathrm{C} 15$ & 86 & 11.3 & 75 & 9.6 & 83 & 10.6 & 79 & 9.9 & 68 & 8.4 \\
\hline Stomach & $\mathrm{C} 16$ & 99 & 13 & 105 & 13.5 & 115 & 14.6 & 98 & 12.3 & 106 & 13.1 \\
\hline Segmented intestine & $\mathrm{C} 18$ & 22 & 2.9 & 31 & 4 & 25 & 3.2 & 30 & 3.8 & 32 & 4 \\
\hline $\begin{array}{l}\text { Rectum, rectosigmoid } \\
\text { junction, anus }\end{array}$ & C19-C21 & 32 & 4.2 & 33 & 4.2 & 30 & 3.8 & 30 & 3.8 & 45 & 5.6 \\
\hline Liver & $\mathrm{C} 22$ & 45 & 5.9 & 32 & 4.1 & 29 & 3.7 & 52 & 6.5 & 40 & 4.9 \\
\hline Pancreas & $\mathrm{C} 25$ & 20 & 2.6 & 31 & 4 & 29 & 3.7 & 26 & 3.3 & 25 & 3.1 \\
\hline Larynx & $\mathrm{C} 32$ & 12 & 1.6 & 16 & 2.1 & 11 & 1.4 & 11 & 1.4 & 9 & 1.1 \\
\hline Trachea,bronchus, lung & $\mathrm{C} 33-\mathrm{C} 34$ & 127 & 16.6 & 127 & 16.3 & 116 & 14.8 & 125 & 15.7 & 146 & 18 \\
\hline $\begin{array}{l}\text { Bones and articular } \\
\text { cartilages }\end{array}$ & $\mathrm{C} 40-\mathrm{C} 41$ & 5 & 0.7 & 2 & 0.3 & 8 & 1 & 3 & 0.4 & 10 & 1.2 \\
\hline $\begin{array}{l}\text { Connective and other } \\
\text { soft tissues }\end{array}$ & $\begin{array}{l}\text { C } 45, C 46.1, C 47, \\
\text { C49 }\end{array}$ & 8 & 1 & 9 & 1.2 & 4 & 0.5 & 4 & 0.5 & 5 & 0.6 \\
\hline Skin melanoma & $\mathrm{C} 43$ & 8 & 1 & 1 & 0.1 & 3 & 0.4 & 4 & 0.5 & 1 & 0.1 \\
\hline Other skin cancers & $\mathrm{C} 44, \mathrm{C} 46.0$ & 0 & 0 & 0 & 0 & 0 & 0 & 0 & 0 & 5 & 0.6 \\
\hline Breast & $\mathrm{C} 50$ & 45 & 5.9 & 64 & 8.2 & 68 & 8.6 & 70 & 8.8 & 60 & 7.4 \\
\hline Uterine cervix & $\mathrm{C} 53$ & 31 & 4.1 & 26 & 3.3 & 29 & 3.7 & 41 & 5.2 & 37 & 4.6 \\
\hline Uterine body & $\mathrm{C} 54$ & 11 & 1.4 & 19 & 2.4 & 7 & 0.9 & 11 & 1.4 & 13 & 1.6 \\
\hline Ovary & C56 & 21 & 2.8 & 32 & 4.1 & 22 & 2.8 & 20 & 2.5 & 29 & 3.6 \\
\hline Prostate gland & C61 & 6 & 0.8 & 13 & 1.7 & 6 & 0.8 & 17 & 2.1 & 12 & 1.5 \\
\hline Testis & C62 & 2 & 0.3 & 0 & 0 & 4 & 0.5 & 3 & 0.4 & & 0 \\
\hline Kidney & C64 & 9 & 1.2 & 12 & 1.5 & 14 & 1.8 & 13 & 1.6 & 26 & 3.2 \\
\hline Bladder & $\mathrm{C} 67$ & 16 & 2.1 & 11 & 1.4 & 8 & 1 & 6 & 0.8 & 9 & 1.1 \\
\hline $\begin{array}{l}\text { Eye and appendages of } \\
\text { the eye }\end{array}$ & C69 & 0 & 0 & 2 & 0.3 & 1 & 0.1 & & 0 & & 0 \\
\hline Brain and CNS & C70-C72 & 6 & 0.8 & 17 & 2.2 & 7 & 0.9 & 19 & 2.4 & 25 & 3.1 \\
\hline Thyroid body & $\mathrm{C} 73$ & 6 & 0.8 & 4 & 0.5 & 4 & 0.5 & 7 & 0.9 & 2 & 0.2 \\
\hline Malignant lymphomas & $\mathrm{C} 81-\mathrm{C} 90$ & 17 & 2.2 & 16 & 2.1 & 17 & 2.2 & 8 & 1 & 10 & 1.2 \\
\hline Leukemia & C91C95,C96 & 25 & 3.3 & 17 & 2.2 & 25 & 3.2 & 13 & 1.6 & 25 & 3.1 \\
\hline Others & & 40 & 5.2 & 25 & 3.2 & 31 & 3.9 & 49 & 6.2 & 44 & 5.4 \\
\hline
\end{tabular}

- tumors of the esophagus; fourth - tumors of breast cancer; fifth - tumors of the liver; six - tongue, oral cavity, pharynx mouth and throat cancer. Malignant neoplasms of the female reproductive system (tumors of the cervix and body of uteri, ovary) and tumors in the blood and lymphatic system (malignant lymphoma, leukemia) bring in a significant proportion in mortality rate of region population. Quite high mortality rates are caused by tumors settled in the colon and straight intestine, pancreas, kidneys, larynx, bladder and skin.

\section{Discussion}

As a result it is specified that within the territory of Aktobe region there are some special aspects of malignant tumors morbidity rates and patterns among adults as well as children and teenagers. The uptrend in cumulated measure of oncopathology rate for last ten years takes attention. The first place among women is taken by oncopathology of reproductive system, and among men the leading positions are taken up by neoplasms of trachea, bronchus, lung and stomach. Among children, both girls and boys, the significant proportion of malignant neoplasms prevalence is taken by oncopathology in hematopoietic system (acute lymphocytic leukemia, lymphosarcoma, Hodgkin's disease, acute myeloid leukemia); it is followed by brain and central nervous system, bones and articular cartilages, kidneys, eye and its appendages, bladder, testicular and pancreas tumors.The hematopoietic tissue and lymph are the main oncopathology among boys and girls. 
Aggregate data of population mortality rate caused by oncopathology in Aktobe region, in absolute numbers as well as per 100 thousand people had a tendency to increase during research time. Wherein the mortality rate is absolutely differentiated by tumors localization in a particular organ or tissue.

Investigation of neoplasms prevalence and causes, cancer incidence structural features and blastemas mortality rate for different population groups, including children and teenagers, gives a new perspective for determination the oncology disease causes and the factors which hasten their onset. Numerous epidemiological research works in the sphere of malignant tumors incidence, based on geographical, mineralogical and geological environment features, the ethnic population make-up, social traditions, bad habits and occupational factors are presented in works of Moore et al., 2010; Kutikhin et al., 2012; Moore et al., 2009; Cambra et al., 2011; Crouse et al., 2010.

A fair quantity of researches pursued in West Kazakhstan, more specifically in Aktobe region revealed the presence of ecological relationships between environmental, social factors and medical condition of local people. The decrease of immunologic responsiveness and accumulation of heavy metals in biological medias (Zasorin et al., 2012; Mamyrbayev et al., 2012), the growth of allergic diseases occurrence (Mamyrbayev et al., 2012), the formation of unfavourable social factors aggregation (Battakova et al., 2014; Bekmukhambetov et al., 2015), lesion of nutritional status among local population (Battakova et al., 2014) have resulted in decline of general health indicators among adult as well as young population (Kenesariyev et al., 2012; Mamyrbayev et al., 2013). In addition to the above it is found out that the invalidism level among region population has increased; the nature of disability and incapacitation mortality rates are determined by structure of morbidity among children and adults (Mamyrbayev, Kurmashev et al., 2013)..

As it is known, a multi variant analysis, which defines the human environment, allows to substantiate the interpretation of malignant tumors prevalence and its causes. Where in the expression level of many risk factors is determined by regional specific features and lifestyle conditions. Aggregate factors affecting the population determine age specific patterns and stable structural relations of malignant neoplasms various nosological forms. The statistical and epidemiological data for the malignant neoplasms incidence among different population groups and mortality caused by them is the basis for development of regional and national antitumor programs and making of substantiated management decisions.

\section{References}

Battakova Zh., BekmukhambetovY., Takmurziyeva G. et al (2014). Standardized European Childhood Obesity Surveillance System. Eurasian J Biomedicine, 7/2, 112-4.

Battakova Zh, Bekmukhambetov Y, Tokmurziyeva G. Nutrition and childhood obesity monitoring as a healthy lifestyle factor. Euras J Biomedicine, 7/2, 116-21.
Bekmukhambetov E, Mamyrbayev A, Dzharkenov T. (2015). Questions of development of fundamental and applied problems of preservation of children's health and reproductive health. Astana Med J, 1, 89-96.

Bekmukhambetov Y, Imangazina Z, Jarkenov T, et al (2015). Cancer incidence and mortality data in aktobe, west kazakhstan, 2000-2010. Asian Pac J Cancer Prev, 16, 2379-83.

Bermagambetova S, Karimov T, Zinalieva A, et al (2015). Characteristics of nutrition status of adolescents Aktobe oblast. Med J West Kazakhstan, 2, 26-9.

Bilyalova Z, Igissinov N, Moore M, et al (2012). Epidemiological evalution of breast cancer in ecological areas Kazakhstan - association with pollution emissions. Asian Pac J Cancer Prev, 13, 2341-4.

Cambra K, Martinez-Rueda T, Alonso-Fustel E, et al (2011). Mortality in small geographical areas and proximity to air polluting industries in the Basque Country (Spain). Occup Environ Med, 68, 140-7.

Crouse D, Goldberg M, Ross N, et al (2010). Postmenopausal breast cancer is associated with exposure to traffic-related air pollution in Montreal, Canada: a case-control study. Environ Health Perspect, 118, 1578-83.

Igissinov N, Kulmirzayeva D, Moore M, et al (2014). Epidemiological assessment of leukemia in Kazakhstan. 2003-2012. Asian Pac J Cancer Prev, 15, 6969-72.

Igissinov N, Zatoskikh V, Moore M, et al (2013). Laryngeal cancer in Kazakhstan - ethnic, age and gender differences over time. Asian Pac J Cancer Prev, 14, 7033-8.

Kenesariyev U, Erzhanova A, Amrin M, et al (2012). Hygienic assessment of morbidity in the region of the Karachaganak field. Hygiene Sanitat, 3, 83-6.

Kutikhin A, Yuzhalin A, Brailovskiy V, et al (2012). Analysis of cancer incidence and mortality in the industrial region of South-East Siberia from 1991 through 2010. Asian Pac J Cancer Prev, 13, 5189-93.

Mamyrbayev A, Sukashev T, Alimbaev S, et al (2013). Assessment of morbidity cross-border territories. Med $J$ West Kazakhstan, 1-2, 67-71.

Mamyrbayev A, Bekmukhambetov E, Zasorin B, et al (2012). The metal content in the hair and blood of the child population Aktyubinsk region. Hygiene Sanitat, 3, 61-2.

Mamyrbayev A, Kurmashev J, Karashova G, et al (2013). Indicators of disability and deaath in some areas of crossborder territory of the West Kazakhstan. Med J West Kazakhstan, 3, 47-52.

Mamyrbayev A, Makenova A, Doskabulova D, Kenesova A (2014). The ecological status of the Aral Sea region. Academic J Western Siberia, 5, 107-8.

Mamyrbayev A, Sakebaeva L, Satybaldiyeva W, et al (2012). The role of stress in shaping antropotehnogennoy allergic disease. Hygiene Sanitat, 3, 25-7.

Moore M, Aitmurzaeva G, Arsykulov Z, et al (2009). Chronic disease prevention research in Central Asia, the Urals Siberia and Mongolia - past, present and future. Asian Pac J Cancer Prev, 10, 987-96.

Moore M, Eser S, Igisinov N, et al (2010). Cancer epidemiology and control in north-western and central Asia - past, present and future. Asian Pac J Cancer Prev, 11 (suppl), 17-32.

Urgushbaeva G, Kibataev K, Mamyrbayev A (2015). Environmental effects of nuclear explosions in western Kazakhstan. Med Int Med Sci J, 2, 52-4.

Zasorin B., Ermuhanova L. (2012). Environmental influence on the immunological resistance of the organism. Hygiene Sanitat, 3, 8-9. 